\title{
Other benefits of intra-articular injection of tranexamic acid in primary total knee arthroplasty apart from reducing blood transfusion rates
}

\author{
Eklem içi tranekzamik asit enjeksiyonunun primer total diz artoplastisinde \\ kan transfüzyonu oranlarını azaltmasından başka faydaları
}

\author{
Bahattin Kerem Aydın, MD., Fatih Durgut, MD., Ömer Faruk Erkoçak, MD., Mehmet Ali Acar, MD. \\ Department of Orthopedics and Traumatology, Medical Faculty of Selçuk University, Konya, Turkey
}

\begin{abstract}
Objectives: This study aims to evaluate the effect of intraarticular tranexamic acid (TA) administration on the amount of blood in the drains, the amount of blood transfusion, length of hospital stay, and the total cost in total knee arthroplasty (TKA) patients.

Patients and methods: The study included a total of 118 patients (24 males, 94 females; mean age 67.0 years, range 52 to 81 years) who underwent primary unilateral TKA surgery. Patients were divided into two groups as 58 patients who were performed intra-articular injection of $2 \mathrm{~g}$ TA after closure of articular capsule (TA group; 10 males, 48 females, mean age 65.6 years; range 55 to 80 years) and 60 patients who were not performed any intra-articular injection (non-TA group; 14 males, 46 females; mean age 68.3 years; range 52 to 81 years). The maximum difference between pre- and postoperative hemoglobin levels, the amount of blood in the drains, the amount of blood transfusion, length of hospital stay, and cost of each patient were recorded.
\end{abstract}

Results: The mean difference between pre- and postoperative hemoglobin levels were higher in the non-TA group $(1.7 \mathrm{~g} / \mathrm{dL}$ vs $2.6 \mathrm{~g} / \mathrm{dL}, \mathrm{p}<0.05)$. The mean amounts of blood in drains $(327.5 \mathrm{~mL}$ vs $800.0 \mathrm{~mL}, \mathrm{p}<0.05)$, the amounts of blood transfusions ( 0 units vs 10 units, $\mathrm{p}<0.05)$, the mean lengths of hospital stay (4.03 days vs 4.53 days, $\mathrm{p}<0.05)$, and the hospital costs $(1,935.26$ United States dollars vs 1,959.64 United States dollars, $\mathrm{p}<0.05)$ were lower in TA group.

Conclusion: Administration of intra-articular TA during primary TKA may reduce blood loss and the need for blood transfusion while significantly shortening the postoperative length of hospital stay and reducing the total hospital costs.

Keywords: Blood loss; hospital cost; total knee arthroplasty; tranexamic acid.

\section{ÖZ}

Amaç: $\mathrm{Bu}$ çalışmada total diz artroplastisi (TDA) hastalarında eklem içi tranekzamik asit (TA) uygulamasının drenlerdeki kan miktarına, kan transfüzyonu miktarına, hastanede kalış süresine ve toplam maliyete etkisi değerlendirildi.

Hastalar ve yöntemler: Çalışmaya TDA cerrahisi uygulanan toplam 118 hasta dahil edildi (24 erkek, 94 kadın; ort. yaş 67.0; dağılım 52-81 yıl). Hastalar eklem kapsülünün kapatılmasının ardından eklem içi 2 g TA uygulanan 58 hasta (TA grubu; 10 erkek, 48 kadın ort. yaş 65.6; dağılım 55-80 yıl) ve herhangi bir eklem içi enjeksiyon uygulanmayan 60 hasta (TA'sız grup; 14 erkek, 46 kadın; ort. yaş 68.3 ; dağılım 52-81 yıl) olarak iki gruba ayrıldı. Her hastanın ameliyat öncesi ve sonrası hemoglobin düzeyleri arasındaki maksimum farklılık, drenlerdeki kan miktarı, kan transfüzyonu miktarı, hastanede kalış süresi ve maliyeti kaydedildi.

Bulgular: Ameliyat öncesi ve sonrası hemoglobin düzeylerindeki ortalama farklılık TA'sız grupta daha yüksek idi (1.7 g/dL'ye karşın $2.6 \mathrm{~g} / \mathrm{dL}, \mathrm{p}<0.05)$. Drenlerdeki ortalama kan miktarları (327.5 mL'ye karşın 800.0 mL, p<0.05), kan transfüzyonu miktarları (0 üniteye karşın 10 ünite, $\mathrm{p}<0.05$ ), ortalama hastanede kalış süreleri (4.03 güne karşın 4.53 gün, $\mathrm{p}<0.05)$ ve hastane maliyetleri $(1.935,26$ Amerika Birleşik Devletleri dolarına karşın 1.959,64 Amerika Birleşik Devletleri doları, $\mathrm{p}<0.05)$ TA grubunda daha düşük idi.

Sonuç: Primer TDA sırasında eklem içi TA uygulaması kan kaybını ve kan transfüzyonu gereksinimini azaltırken ameliyat sonrası hastanede kalış sürelerini kısaltıp toplam hastane maliyetlerini anlamlı şekilde azaltabilmektedir.

Anahtar sözcükler: Kan kaybı; hastane maliyeti; total diz artroplastisi; tranekzamik asit.

- Received: July 18, 2016 Accepted: January 16, 2017

- Correspondence: Bahattin Kerem Aydın, MD. Selçuk Üniversitesi Tıp Fakültesi Ortopedi ve Travmatoloji Anabilim Dalı, 42100 Selçuklu, Konya, Turkey. Tel: +90 332 - 2415000 / 45010 e-mail: bkaydin@yahoo.com 
The number of total knee arthroplasty (TKA) surgeries has been increasing. ${ }^{[1]}$ Blood loss is one of the well-known complications of this procedure which can lead to long hospital stay, postoperative morbidity, and delay in postoperative rehabilitation of the patients. ${ }^{[2,3]}$ Antifibrinolytic medications, such as tranexamic acid (TA), have been used in elective orthopedic surgeries perioperatively to reduce the bleeding and also blood transfusions. ${ }^{[4]}$

Topical use of TA has been becoming popular recently as it has the advantages of being easy to administer, providing a maximum concentration at the bleeding site, and inducing partial microvascular hemostasis by stopping fibrin clot dissolution in the affected area. Some studies about topical administration of TA showed reliable evidence that it was effective in reducing total blood loss and blood transfusion rate compared with the placebo ${ }^{[5-9]}$ and also intravenous (IV) administrations. Topical use of TA has been shown to reduce postoperative swelling, leading to improved wound healing, reduced pain, and more rapid rehabilitation. ${ }^{[5,7]}$

Up to date, limited number of publications has been published about effects of topical use of TA on the length of hospital stay and the total cost due to knee arthroplasty. ${ }^{[10,11]}$ Therefore, in this study, we aimed to evaluate the effect of intra-articular TA administration on the amount of blood in the drains, the amount of blood transfusion, length of hospital stay, and the total cost in TKA patients.

\section{PATIENTS AND METHODS}

This retrospective observational study included a total of 118 patients (24 males, 94 females; mean age 67.0 years; range 52 to 81 years) who underwent primary unilateral TKA surgery between 1 August 2014 and 31 May 2015 at the Medical Faculty of Selçuk University. Patients were divided into two groups as 58 patients who were performed intra-articular injection of $25 \mathrm{~mL}$ normal saline mixed with $2 \mathrm{~g}$ TA (Transamine, Actavis, Istanbul, Turkey) after closure of articular capsule (TA group; 10 males, 48 females; mean age 65.6 years; range 55 to 80 years) and 60 patients who were not performed any intraarticular injection (non-TA group; 14 males, 46 females; mean age 68.3 years; range 52 to 81 years). Patients with American Society of Anaesthesiologists (ASA) physical status classification greater than II, bilateral procedures, unicompartmental knee arthroplasty, revision surgery, known hypersensitivity to TA, active or past intravascular clotting disorders (recent cerebrovascular event, deep vein thrombosis or pulmonary embolism, cardiac stent placement) were excluded. The study protocol was approved by the Medical Faculty of Selçuk University Ethics Committee. A written informed consent was obtained from each patient. The study was conducted in accordance with the principles of the Declaration of Helsinki.

Standard Hemovac drains (B-Vak $400 \mathrm{~mL}$ Wound Drainage System $14 \mathrm{CH}$, Bıçakcılar Tıbbi Cihazlar San. ve Tic. A.Ş., İstanbul, Turkey) were used for all patients. Tourniquets were released after the application of compressive dressings in all patients. The clamps of the drains were opened 30 minutes postoperatively and removed 24 hours later. All patients received enoxaparin as prophylaxis against deep vein thrombosis 12 hours preoperatively and the next injection was at eight hours postoperatively.

A transfusion threshold of hemoglobin $8 \mathrm{~g} / \mathrm{dL}$ was routinely utilized. Also, the patients who had hemoglobin levels between $8 \mathrm{~g} / \mathrm{dL}$ and $10 \mathrm{~g} / \mathrm{dL}$ with hypotension symptoms were considered for blood transfusion as published in previous papers. ${ }^{[2,7]}$ The patients were discharged when they were mobile independently, had no pain complaint, and had dry wound after they had active 90 degrees knee flexion and full extension. Standard follow-up visits were performed for all patients by the orthopedic surgeons in the clinic at postoperative $15^{\text {th }}$ day, and sixth and $12^{\text {th }}$ weeks. Data on clinical and surgical characteristics as well as complications (such as deep vein thrombosis, pulmonary embolism, and wound infection) were obtained from electronic medical records.

Cost data were obtained from an institutional cost and utilization database that contained standardized cost of each service or procedure provided to patients by Selçuk University Medical Faculty Hospital in constant Turkish Liras (TL). At the end of the study duration, 1 US dollar was 2.67 TL (June $1^{\text {st }}$, 2015).

The maximum difference between pre- and postoperative hemoglobin levels, amount of blood in the drains, amount of blood transfusion, length of hospital stay, and cost of each patient to the hospital were documented.

\section{Statistical analysis}

All statistical analyses were performed using IBM SPSS version 20.0 software (IBM Corp., Armonk, NY, USA). Binary conditions, such as gender, were compared using Pearson chi-square and Fisher's exact tests. Continuous factors, such as age and body mass index, were compared with Independent t-test if the distributions were stochastically ordered. 
TABLE I

Demographics of study groups

\begin{tabular}{|c|c|c|c|c|c|}
\hline & \multicolumn{2}{|c|}{ TA group $(n=58)$} & \multicolumn{2}{|c|}{ Non-TA group $(n=60)$} & \multirow[b]{2}{*}{$p$} \\
\hline & $\mathrm{n}$ & Mean $\pm S D$ & $\mathrm{n}$ & Mean \pm SD & \\
\hline Age (years) & & $68.3 \pm 6.9$ & & $65.6 \pm 6.4$ & 0.035 \\
\hline Gender & & & & & $>0.05$ \\
\hline Female & 48 & & 46 & & \\
\hline Male & 10 & & 14 & & \\
\hline Body mass index $\left(\mathrm{kg} / \mathrm{m}^{2}\right)$ & & $32.6 \pm 3.5$ & & $31.8 \pm 3.5$ & $>0.05$ \\
\hline Side & & & & & $>0.05$ \\
\hline Right & 36 & & 30 & & \\
\hline Left & 22 & & 30 & & \\
\hline
\end{tabular}

TA: Tranexamic acid; SD: Standard deviation.

Mann-Whitney U test was used for distributions that were not stochastically ordered. Statistical significance was defined as a $p$ value of $<0.05$.

\section{RESULTS}

There were no statistically significant differences in demographic characteristics between the TA and non-TA groups except the age parameter. TA group was statistically older by 2.7 years (68.4 years vs 65.7 years $\mathrm{p}<0.05$ ) than non-TA group (Table I). Body mass indices were similar $\left(32.89 \mathrm{~kg} / \mathrm{m}^{2}\right.$ vs $31.7 \mathrm{~kg} / \mathrm{m}^{2}$, $\mathrm{p}=0.23$ ).

The mean difference between the pre- and postoperative hemoglobin levels was significantly higher in the non-TA group $(1.7 \mathrm{~g} / \mathrm{dL}$ vs $2.6 \mathrm{~g} / \mathrm{dL}$, $\mathrm{p}<0.05)$. The mean amount of blood in drains, the need of blood transfusions, the mean length of hospital stay, and the total hospital cost of patients were shown in Table II.

Ten patients $(17 \%)$ of the non-TA group required blood transfusion compared to none in the TA group. Eight patients required two, and two patients required one unit of blood transfusions. The comparison of the groups according to the need of blood transfusion was statistically significant $(\mathrm{p}<0.005)$.

The mean length of hospital stay was significantly shorter in TA group although the mean difference was shorter than one day (4.03 days vs 4.53 days). The total hospital cost of the patients in TA group was significantly lower compared to the non-TA group patients.

Three patients (one in TA and two in nonTA groups) readmitted to hospital secondary to wound discharge, which was continuing for ten days postoperatively. All of them were hospitalized for detailed follow-up and wound dressings for three more days. No medication was given to the patients during their second hospitalization. The second hospitalization period was added to their previous length of hospital stay. Complaints were relieved in three days after the readmissions. None of the patients had complaints related to anemia or thromboembolic events during their follow-up visits. There was no rehospitalization history among

TABLE II

Results of study groups

\begin{tabular}{lcccc}
\hline & TA group & & Non-TA group & \\
\cline { 2 - 2 } & Mean \pm SD & & Mean $\pm S D$ & \\
\hline Hemoglobin difference (gr/L) & $1.70 \pm 0.8$ & & $2.67 \pm 0.9$ & $<0.001$ \\
Drain (mL) & $327.6 \pm 170.4$ & & $800.0 \pm 246.0$ & $<0.005$ \\
Transfusion (units) & 0 & 10 & $<0.001$ \\
Length of hospital stay (day) & $4.03 \pm 1.2$ & & $4.53 \pm 1.1$ & $<0.001$ \\
Total cost (TL) & $5,167.20 \pm 133.95$ & & $5,232.24 \pm 186.34$ & $<0.05$ \\
Total cost (USD) & $1,935.26 \pm 50.16$ & & $1,959.64 \pm 69.79$ & $<0.05$ \\
\hline
\end{tabular}

SD: Standard deviation; TL: Turkish Lira; USD: United States Dollar. 
the remaining 115 patients who were questioned during their second, sixth, and $12^{\text {th }}$ week outpatient clinic controls.

The mean total hospital costs in TA and nonTA groups were 5,167.16 TL (1,935.26 United States dollars [USD]) and 5,232.24 TL (1,959.64 USD). The cost was significantly lower in TA group $(p<0.05)$. The implant cost was unique, 3,708.00 TL, for all the patients, which is determined by Turkish Health Security System. The remaining cost includes all hospitalization costs other than the implant cost.

\section{DISCUSSION}

There is no consensus about the amount and the method for topical administration of TA in arthroplasty patients. ${ }^{[5-10,12,13]}$ The patients in this study received $2 \mathrm{~g}$ TA intraarticularly at the end of the surgery before the skin closure similar to the previous published papers ${ }^{[5,13]}$ while the others did not receive any antifibrinolytics.

The mean amount of blood in drains was $430 \mathrm{~mL}$ lower in TA group. As we performed all the surgeries under tourniquet, the amount of blood in the drains can be suggestive about the perioperative bleeding. Also, the hemoglobin difference between pre- and postoperative values was significantly lower in TA group. This result also supports the affectivity of topical TA in knee arthroplasty patients. None of the patients required blood transfusion in TA group although 10 of the 60 patients in non-TA group required a total of 18 units of blood transfusion.

Of the total hospital costs, 3,708.00 TL $(1,388.76$ USD) is the implant cost which is standard for all the patients. The anesthesia and operating room costs were between $400 \mathrm{TL}-800 \mathrm{TL}$ (150 USD - 301 USD) according to spinal or general anesthesia. In the literature, similar studies were reported about the cost-effectiveness of IV use of TA in arthroplasty surgeries. ${ }^{[2,4]}$ To our knowledge, this is the third study about the effect of topical TA on the hospital cost in knee arthroplasty surgery. However, our administration method was different from the previous studies as we applied TA intraarticularly after the closure of joint capsule. Topical TA application may have a positive effect on providing fast recovery as suggested by the significantly shorter length of hospital stay compared to non-TA group.

This study has some limitations. First, this is a nonblind retrospective study from a single institution using a prospective database. A prospective doubleblind study would be a superior method to track all the patients' cost with longer follow-up period.
The separation of related factors such as length of hospital stay and the cost could not be made due to the retrospective design. Furthermore, we used $2 \mathrm{~g}$ TA diluted in $25 \mathrm{~mL}$ saline which can be considered as a concentrated solution. There is no consensus about the dose and the concentration for the intra-articular use of TA. Also, we do not know clearly the chemical side effects of intra-articular TA use. We believe that more studies are needed to evaluate the dose-related chemical side effects for intra-articular administration of TA. Certainly, the single-institution results cannot be generalized to other institutions. Another limitation is the short follow-up time. Controlled prospective studies with longer follow-up periods are needed for analyzing the main complications of primary knee arthroplasty such as infection and thromboembolic events with the use of topical TA. Also, the control group patients were older by 2.7 years and the surgeons of the groups were different. This limitation was minimalized by limiting the patient population to healthy patients (maximum ASA class II, similar body mass index, and gender).

In conclusion, single dose topical application of TA may have positive effects on knee arthroplasty patients by reducing the need of blood transfusion, shortening the postoperative length of hospital stay, and also reducing the total hospital costs. However, further prospective controlled clinical studies are needed to support these findings.

\section{Declaration of conflicting interests}

The authors declared no conflicts of interest with respect to the authorship and/or publication of this article.

\section{Funding}

The authors received no financial support for the research and/or authorship of this article.

\section{REFERENCES}

1. Eroğlu M, Kokulu S, Koca HB, Demirboğan ME, Baki ED, Özcan Ö. The effects of general and spinal anesthesia on systemic inflammatory response in patients undergoing total knee arthroplasty. Eklem Hastalik Cerrahisi 2016;27:153-9.

2. Gillette BP, Maradit Kremers H, Duncan CM, Smith HM, Trousdale RT, Pagnano MW, et al. Economic impact of tranexamic acid in healthy patients undergoing primary total hip and knee arthroplasty. J Arthroplasty 2013;28:137-9.

3. Browne JA, Adib F, Brown TE, Novicoff WM. Transfusion rates are increasing following total hip arthroplasty: risk factors and outcomes. J Arthroplasty 2013;28:34-7.

4. Atik OS. Does tranexamic acid reduce blood loss and blood transfusion requirement in knee arthroplasty? Eklem Hastalik Cerrahisi 2012;23:166-7. 
5. Ishida K, Tsumura N, Kitagawa A, Hamamura S, Fukuda $\mathrm{K}$, Dogaki $\mathrm{Y}$, et al. Intra-articular injection of tranexamic acid reduces not only blood loss but also knee joint swelling after total knee arthroplasty. Int Orthop 2011;35:1639-45.

6. Çavuşoğlu AT, Ayanoğlu T, Esen E, Atalar H, Turanlı S. Is intraarticular administration of tranexamic acid efficient and safe as systemic administration in total knee arthroplasty? Single center, randomized, controlled trial. [Article in Turkish] Eklem Hastalik Cerrahisi 2015;26:164-7.

7. Seo JG, Moon YW, Park SH, Kim SM, Ko KR. The comparative efficacies of intra-articular and IV tranexamic acid for reducing blood loss during total knee arthroplasty. Knee Surg Sports Traumatol Arthrosc 2013;21:1869-74.

8. Yang Y, Lv YM, Ding PJ, Li J, Ying-Ze Z. The reduction in blood loss with intra-articular injection of tranexamic acid in unilateral total knee arthroplasty without operative drains: a randomized controlled trial. Eur J Orthop Surg Traumatol 2015;25:135-9.
9. Wang H, Shen B, Zeng Y. Comparison of topical versus intravenous tranexamic acid in primary total knee arthroplasty: a meta-analysis of randomized controlled and prospective cohort trials. Knee 2014;21:987-93.

10. Chimento GF, Huff T, Ochsner JL Jr, Meyer M, Brandner L, Babin S. An evaluation of the use of topical tranexamic acid in total knee arthroplasty. J Arthroplasty 2013;28:74-7.

11. Tuttle JR, Ritterman SA, Cassidy DB, Anazonwu WA, Froehlich JA, Rubin LE. Cost benefit analysis of topical tranexamic acid in primary total hip and knee arthroplasty. J Arthroplasty 2014;29:1512-5.

12. Patel JN, Spanyer JM, Smith LS, Huang J, Yakkanti MR, Malkani AL. Comparison of intravenous versus topical tranexamic acid in total knee arthroplasty: a prospective randomized study. J Arthroplasty 2014;29:1528-31.

13. Georgiadis AG, Muh SJ, Silverton CD, Weir RM, Laker MW. A prospective double-blind placebo controlled trial of topical tranexamic acid in total knee arthroplasty. J Arthroplasty 2013;28:78-82. 